\title{
Obesity in Older Adults Indonesia: The Role of Healthy Behaviour Factors and Metabolic Syndrome
}

\author{
Sudikno ${ }^{1}$, Ning Sulistyowati ${ }^{1}$, Olwin Nainggolan ${ }^{1} \&$ Dwi Hapsari Tjandrarini ${ }^{1}$ \\ ${ }^{1}$ National Institute of Health Research and Development, Ministry of Health, Jakarta, Indonesia \\ Correspondence: Sudikno, National Institute of Health Research and Development, JL. Percetakan Negara 29, \\ Jakarta Pusat 10560, Indonesia. Tel : 62-813-1635-0502.
}

Received: March 22, 2021 Accepted: April 27, 2021 Online Published: May 17, 2021

doi:10.5539/gjhs.v13n6p124 URL: https://doi.org/10.5539/gjhs.v13n6p124

\begin{abstract}
Obesity in older adults has been a health problem in both developed and developing countries. This study aimed to determine the problem of obesity in the older adults group according to behavioral factors and metabolic syndrome. This study used a cross-sectional design. The number of samples analyzed was 5120 people, all of which were older adults aged 60 years and over. The prevalence of obesity in older adults was 17.6 percent. The results of the advanced analysis also showed a correlation between the variables gender, age, region, education, smoking behavior, and levels of LDL cholesterol, triglycerides, HDL cholesterol, hypertension, and diabetes mellitus with the incidence of obesity in the older adults.
\end{abstract}

Keywords: obese, older adults, metabolic syndrome

\section{Introduction}

The number of people who are overweight and obese in the world has nearly tripled over the past three decades (from 857 million in 1980 to 2.1 billion in 2013), including older adults (Zhao et al., 2014) whose number is estimated to reach around 22 percent of the world's population by 2050 (Scully, 2012 ;WHO, 2007). The World Population Prospect (2019) revealed that the world's older adult population increases from year to year. Based on estimates, the older adult population in Indonesia in 2020 is around 273 thousand, increasing by around 30 thousand from 2010 (United Nations, 2019). Based on data from the 2014 National Socio-Economic Survey, the number of older adults in Indonesia has reached 20.24 million, equivalent to 8.03 percent of the total population of the country in 2014 (Central Bureau of Statistics, 2015).

The normal aging process is characterized by an increase in fat mass and fat distribution from adipose tissues (Ponti et al., 2020). These changes can have consequences on metabolic syndrome (MetS) risk factors. Women are prone to experience increased visceral fat during menopause (Lovejoy et al., 2008).

The results of the 2010 Basic Health Research (Riskesdas) revealed that the percentages of obesity (BMI> $=27$ $\mathrm{kg} / \mathrm{m}^{2}$ ) in men and women aged 60 years and over were 5.6 and 9.9, respectively (Ministry of Health Republic of Indonesia, 2010).

Klein (2007) stated that people with a BMI of $\geq 30 \mathrm{~kg} / \mathrm{m}^{2}$ are at a higher risk of experiencing adverse health problems than those with a BMI between $25.0-29.9 \mathrm{~kg} / \mathrm{m}^{2}$ or those with a BMI between $18.5-24.9 \mathrm{~kg} / \mathrm{m}^{2}$. Obesity is associated with physical, psychosocial, and economic burdens globally (WHO, 2000). Obesity has also been shown to be a risk factor for various diseases such as cardiovascular disease, cancer, type 2 diabetes, and psychiatric conditions (Guh et al., 2009; Scott et al., 2009; Wolin et al., 2010). Other evidence suggested an association between increased body mass index and pain (Hitt et al., 2007), fatigue, and sleep disturbances (Resnick et al., 2006).

Basic Health Research in 2013 provided data related to obesity. Previous analysis of obesity and risk factors has been carried out in younger age groups, not in the older adult group (Sudikno et al., 2015). This study aims to determine the problem of obesity in the older adult group according to behavioral factors and metabolic syndrome.

\section{Method}

This study used secondary data provided by the 2013 Riskesdas and used a cross-sectional design. The population in this study were all household members aged 60 years and over in Riskesdas 2013 . The sample was all members 
of the 2013 Riskesdas household aged 60 years and over who were not physically and mentally disabled and had completed data. The number of the sample at the beginning of the analysis was 5145. After correcting the value of the outlier of the variables height, weight, and others, as well as the completeness of the data, the number of the sample analyzed was 5120. This sample size still fulfilled the minimum sample calculation results (Ogston et al., 1991).

The data analyzed in the 2013 Riskesdas was taken from household questionnaires (RKD13.RT), which included place identification (village/kelurahan classification), information on household members (gender, marital status, age, and education), and from individual questionnaires (RKD13. IND), which included smoking habits, physical activity, fruits-and-vegetables-eating habits, diagnosis of hypertension and diabetes mellitus, and measurements (body weight, height, and lipid profile).

Measurement of body weight of the subjects was carried out using a digital weight scale branded "Fesco" having an accuracy of $0.1 \mathrm{~kg}$, which was calibrated every day. The subjects' body height was measured with a "Multifunctional" height measuring instrument with a measuring capacity of two meters and an accuracy of $0.1 \mathrm{~cm}$. The conversion of body weight and height to BMI was carried out according to the BMI categories set by the WHO (2000), namely: $18.5-24.9 \mathrm{~kg} / \mathrm{m}^{2}, 25.0-29.0 \mathrm{~kg} / \mathrm{m}^{2}$, and $\geq 30.0 \mathrm{~kg} / \mathrm{m}^{2}$ (WHO, 2000). In this analysis, a person was said to be obese if his $/$ her BMI was $\geq 25 \mathrm{~kg} / \mathrm{m}^{2}$.

The implementation of the 2013 Riskesdas had obtained ethical approval from the Health Research Ethics Commission (KEPK) of the Health Research and Development Agency of the Ministry of Health Republic of Indonesia with the number LB.02.01/5.2/KE.006/2013.

Variable grouping and coding were performed before data analysis. Variable coding was done based on the level of risk for obesity. Individual characteristics included the variables gender, age, region, education, and marital status. The variables were classified as follows: gender into 1) male and 2) female; age into 1) 76 years and over, 2) 71-75 years, 3) 66-70 years, and 4) 60-65 years; region into 1) rural and 2) urban; education into 1) low and 2) high, and; and marital into 1) married, 2) divorced, and 3) not married.

Health behavior variables included physical activity, smoking behavior, vegetable consumption habits, and fruit consumption habits. Physical activity intensity was grouped into 1) moderate and 2) insufficient. The measurement was done based on a composite calculation of the type and duration of activity (days per week and minutes per day) including the exercise performed. Subjects were considered to have a heavy activity or strenuous exercise if doing exercise 8 times, moderate activity or moderate exercise for doing 4 times, and light activity if doing it 2 times. A person was categorized to have less activity if having a total activity of less than 600 MET (metabolic equivalent) in one week (WHO, 2012). The variable smoking behavior was categorized into 1) never, 2) ever, 3) sometimes, and 4) every day. The vegetables-and-fruits-consuming habit was grouped into 1) every day, 2) not every day, and 3) never.

The variable metabolic syndrome consisted of total cholesterol, LDL, TG, HDL, hypertension, and DM. Total cholesterol (C-total) levels were grouped into 1) normal ( $<200 \mathrm{mg} / \mathrm{dL})$ and 2) high ( $\geq 200 \mathrm{mg} / \mathrm{dL}$ ). LDL cholesterol (C-LDL) levels were divided into 1) normal $(<100 \mathrm{mg} / \mathrm{dL})$ and 2) high $(\geq 100 \mathrm{mg} / \mathrm{dL})$. Levels of HDL cholesterol (C-HDL) were grouped into 1) normal ( $\geq 40 \mathrm{mg} / \mathrm{dL}$ for men and $\geq 50 \mathrm{mg} / \mathrm{dL}$ for women) and 2 . low $(<40 \mathrm{mg} / \mathrm{dL}$ for men and $<50 \mathrm{mg} / \mathrm{dL}$ for women). Meanwhile, triglyceride levels (TG) were grouped into 1) normal ( $<150 \mathrm{mg} / \mathrm{dL})$ and 2) high ( $\geq 150 \mathrm{mg} / \mathrm{dL}$ ) (Grundy et al., 2001; Jellinger et al., 2017; Sun et al., 2014). The variables hypertension and diabetes mellitus were grouped into 1) no and 2) yes, respectively.

Data analysis was carried out in stages, namely univariate, bivariate, and multivariate analyses. Univariate analysis was intended to determine the distribution of the value of each variable, while bivariate analysis aimed to determine the relationship of each risk factor with obesity using the Chi-square test and logistic regression. Meanwhile, multivariate analysis was carried out to determine the association of risk factors together with obesity in older adults using multivariate logistic regression analysis of risk factor models. Multivariate analysis was performed using logistic regression analysis. Variables with a significant value of $p<0.25$ were selected and then included in the multivariate candidate model. All of the analyses were done using statistical software.

\section{Result}

The number of the sample analyzed was 5120 people, consisting of 2554 men (49.9\%) and 2566 women (50.1\%). The results of the univariate analysis showed that the mean age of the respondents was $67.7 \pm 6.6$ years with an average Body Mass Index (BMI) of $21.55 \pm 3.89 \mathrm{~kg} / \mathrm{m}^{2}$. The prevalence of obesity in older adults was found to be 17.6 percent. The lipid profile characteristics of respondents are described in Table 1. The average lipid profile (total cholesterol, LDL, triglycerides, and HDL) in obese respondents was higher than those who were not obese (p 
$<0.005)$.

Table 1. Characteristics of Respondents' Lipid Profiles

\begin{tabular}{llll}
\hline \multirow{2}{*}{ Characteristics of Lipid Profiles } & \multicolumn{2}{l}{ Obese } & \\
\cline { 2 - 3 } & $\begin{array}{l}\text { Yes } \\
\left(>=25 \mathrm{~kg} / \mathrm{m}^{2}\right)\end{array}$ & $\begin{array}{l}\text { No } \\
\left(<25 \mathrm{~kg} / \mathrm{m}^{2}\right)\end{array}$ & \\
\hline Total cholesterol & $210.4 \pm 44.4$ & $193.6 \pm 41.2$ & 0.000 \\
LDL cholesterol & $144.2 \pm 39.3$ & $129.8 \pm 36.5$ & 0.000 \\
Triglycerides & $156.2 \pm 93.5$ & $124.2 \pm 68.5$ & 0.000 \\
HDL cholesterol & $47.9 \pm 13.7$ & $50.7 \pm 13.1$ & 0.000 \\
\hline
\end{tabular}

Table 2 and Table 3 show the characteristics of obesity according to characteristics and behavior. The results of the bivariate analysis showed a significant relationship between the variables gender, age, region, education, physical activity, smoking behavior, vegetable and fruit consumption with obese status in older adults $(\mathrm{p}<0.005)$.

Table 2. Percentage of Obesity in Older Adults according to the characteristics

\begin{tabular}{|c|c|c|c|c|c|}
\hline \multirow{3}{*}{ Characteristics } & \multicolumn{2}{|l|}{ Obese } & \multirow{3}{*}{$\mathrm{N}$} & \multirow{3}{*}{$\mathrm{OR}(95 \% \mathrm{CI})$} & \multirow{3}{*}{$p$-value } \\
\hline & & & & & \\
\hline & $\left(<25 \mathrm{~kg} / \mathrm{m}^{2}\right)$ & $\left(>=25 \mathrm{~kg} / \mathrm{m}^{2}\right)$ & & & \\
\hline Gender & & & & & 0.000 \\
\hline 1. Male & $2198(86.1 \%)$ & $356(13.9 \%)$ & 2554 & Reff & \\
\hline 2. Female & $2022(78.8 \%)$ & $544(21.2 \%))$ & 2566 & $1,66(1,43-1,92)$ & \\
\hline Age (years) & & & & & 0.000 \\
\hline $1.76+$ & $617(91.1 \%)$ & $60(8.9 \%)$ & 677 & Reff & \\
\hline 2. $71-75$ & $715(87.4 \%)$ & $103(12.6 \%)$ & 818 & $1,48(1,05-2,07)$ & \\
\hline 3. $66-70$ & $1073(85.1 \%)$ & $188(14.9 \%)$ & 1261 & $1,80(1,32-2,44)$ & \\
\hline 4. $60-65$ & $1815(76.8 \%)$ & $549(23.2 \%)$ & 2364 & $3,11(2,34-4,12)$ & \\
\hline Region & & & & & 0.000 \\
\hline 1. Rural & $2730(87.4 \%)$ & $394(12.6 \%)$ & 3124 & Reff & \\
\hline 2. Urban & $1490(74.6 \%)$ & $506(25.4 \%)$ & 1996 & $2,35(2,03-2,72)$ & \\
\hline Education & & & & & 0.000 \\
\hline 1. Low & $3892(84.4 \%)$ & $718(15.6 \%)$ & 4610 & Reff & \\
\hline 2. High & $328(64.3 \%)$ & $182(35.7 \%)$ & 510 & $3,00(2,46-3,66)$ & \\
\hline Marital status & & & & & 0.774 \\
\hline 1. Married & $2951(82.2 \%)$ & $637(17.8 \%)$ & 3588 & Reff & \\
\hline 2. Divorced & $1233(82.9 \%)$ & $254(17.1 \%)$ & 1487 & $0,95(0,81-1,12)$ & \\
\hline 3. Not married & $36(80.0 \%)$ & $9(20.0 \%)$ & 45 & $1,15(0,55-2,41)$ & \\
\hline
\end{tabular}


Table 3. Percentage of Obesity in Older Adults by Health Behavior

\begin{tabular}{|c|c|c|c|c|c|}
\hline \multirow{3}{*}{ Healthy Behavior } & \multicolumn{2}{|l|}{ Obese } & \multirow{3}{*}{$\mathrm{N}$} & \multirow{3}{*}{ OR $(95 \% \mathrm{CI})$} & \multirow{3}{*}{$p$-value } \\
\hline & No & Yes & & & \\
\hline & $\left(<25 \mathrm{~kg} / \mathrm{m}^{2}\right)$ & $\left(>=25 \mathrm{~kg} / \mathrm{m}^{2}\right)$ & & & \\
\hline Physical activity & & & & & 0.000 \\
\hline 1. Moderate & $1306(87.8 \%)$ & $181(12.2 \%)$ & 1487 & Reff & \\
\hline 2. Less & $2914(80.2 \%)$ & $719(19.8 \%)$ & 3633 & $1,78(1,49-2,12)$ & \\
\hline Smoking behavior & & & & & 0.000 \\
\hline 1. Never & $2247(78.8)$ & $605(21.2)$ & 2852 & Reff & \\
\hline 2. Ever & $472(81.1)$ & $110(18.9)$ & 582 & $0,41(0,34-0,50)$ & \\
\hline 3. Sometimes & $247(84.9)$ & $44(15.1)$ & 291 & $0,66(0,47-0,92)$ & \\
\hline 4. Every day & 1254 (89.9) & $141(10.1)$ & 1395 & $0,86(0,69-1,08)$ & \\
\hline Vegetable consumption & & & & & 0.005 \\
\hline 1. Every day & $2387(81.1 \%)$ & $557(18.9 \%)$ & 2944 & Reff & \\
\hline 2. Not every day & $1733(84.5 \%)$ & $317(15.5 \%)$ & 2050 & $0,78(0,67-0,91)$ & \\
\hline 3. Never & $100(79.4 \%)$ & $26(20.6 \%)$ & 126 & $1,11(0,71-1,73)$ & \\
\hline Fruit consumption & & & & & 0.000 \\
\hline 1. Every day & $392(69.3 \%)$ & $174(30.7 \%)$ & 566 & Reff & \\
\hline 2. Not every day & $2928(83.1 \%)$ & $597(16.9 \%)$ & 3525 & $0,45(0,37-0,56)$ & \\
\hline 3. Never & $900(87.5 \%)$ & $129(12.5 \%)$ & 1029 & $0,32(0,25-0,41)$ & \\
\hline
\end{tabular}

Table 4 shows the relationship between metabolic syndrome variables (total cholesterol, LDL, TG, HDL, hypertension, and diabetes) and the obese status in older adults.

Table 4. Percentage of Obesity in Older Adults according to Metabolic Syndrome

\begin{tabular}{|c|c|c|c|c|c|}
\hline \multirow[b]{2}{*}{ Metabolic Syndrome } & \multicolumn{2}{|l|}{ Obese } & \multirow[b]{2}{*}{$\mathrm{N}$} & \multirow[b]{2}{*}{$\mathrm{OR}(95 \% \mathrm{CI})$} & \multirow[b]{2}{*}{$p$-value } \\
\hline & $\begin{array}{l}\text { No } \\
\left(<25 \mathrm{~kg} / \mathrm{m}^{2}\right)\end{array}$ & $\begin{array}{l}\text { Yes } \\
\left(>=25 \mathrm{~kg} / \mathrm{m}^{2}\right)\end{array}$ & & & \\
\hline Total cholesterol & & & & & 0.000 \\
\hline 1. Normal $(<240 \mathrm{mg} / \mathrm{dL})$ & $3700(84.1 \%)$ & $698(15.9 \%)$ & 4398 & Reff & \\
\hline 2. $\operatorname{High}(\geq 240 \mathrm{mg} / \mathrm{dL})$ & $520(72 \%)$ & $202(28.0 \%)$ & 722 & $2,05(1,71-2,46)$ & \\
\hline LDL cholesterol & & & & & 0.000 \\
\hline 1. Normal $(<160 \mathrm{mg} / \mathrm{dL})$ & $3410(84.7 \%)$ & $616(15.3 \%)$ & 4026 & Reff & \\
\hline 2. $\operatorname{High}(\geq 160 \mathrm{mg} / \mathrm{dL})$ & $810(74.0 \%)$ & $284(26.0 \%)$ & 1094 & $1,94(1,65-2,27)$ & \\
\hline Triglycerides & & & & & 0.000 \\
\hline 1. Normal $(<200 \mathrm{mg} / \mathrm{dL})$ & $3790(84.1 \%)$ & $714(15.9 \%)$ & 4504 & Reff & \\
\hline 2. High $(\geq 200 \mathrm{mg} / \mathrm{dL})$ & $430(69.8 \%)$ & $186(30.2 \%)$ & 616 & $2,29(1,89-2,77)$ & \\
\hline HDL cholesterol & & & & & 0.000 \\
\hline 1. Normal $(\geq 40 \mathrm{mg} / \mathrm{dL})$ & $3420(83.7 \%)$ & $665(16.3 \%)$ & 4085 & Reff & \\
\hline 2. Low $(<40 \mathrm{mg} / \mathrm{dL})$ & $800(77.3 \%)$ & $235(22.7 \%)$ & 1035 & $1,51(1,27-1,78)$ & \\
\hline
\end{tabular}




\begin{tabular}{|c|c|c|c|c|c|}
\hline \multicolumn{5}{|l|}{ Hypertension } & \multirow[t]{3}{*}{0.000} \\
\hline 1. No & $3319(85.6 \%)$ & $559(14.4 \%)$ & 3878 & Reff & \\
\hline 2. Yes & $901(72.5 \%)$ & $341(27.5 \%)$ & 1242 & $2,24(1,92-2,62)$ & \\
\hline Diabetes & & & & & 0.000 \\
\hline 1. No & $4102(83.4 \%)$ & $816(16.6 \%)$ & 4918 & Reff & \\
\hline 2. Yes & $118(58.4 \%)$ & $84(41.6 \%)$ & 202 & $3,57(2,67-4,78)$ & \\
\hline
\end{tabular}

Table 5 shows a model of the relationship between healthy behavior and metabolic syndrome on obesity in older adults. The results of the multivariate analysis found that the variables gender, age, region, education, smoking behavior, lipid profile (triglycerides, LDL, HDL), hypertension, and diabetes mellitus were associated with obesity in old age. Female respondents had a risk of obesity of 1.38 times higher than that of male respondents. The risk of obesity decreases with age. Respondents aged 60-65 had an obesity risk of 3.1 times higher than that of those aged 76 and over. Respondents aged 66-70 had an obesity risk of 1.8 times higher than that of those aged 76 and over. Respondents aged 71-75 had a risk of obesity by 1.4 times higher than that of those aged 76 and over. Respondents who live in urban areas had a risk of obesity 1.89 times higher than that of those who live in rural areas. Meanwhile, respondents with higher education had a risk of obesity 2.08 times higher than that of those with low education.

Table 5 Model of Correlation between Healthy Behavior and Metabolic Syndrome and Obesity in Older Adults in Indonesia, 2013

\begin{tabular}{|c|c|c|c|}
\hline & B & $\begin{array}{l}\text { Adjusted OR } \\
95 \% \text { CI }\end{array}$ & $\mathrm{p}$ value \\
\hline \multicolumn{4}{|l|}{ Gender } \\
\hline 1. Male & & Reff & \\
\hline 2. Female & 0.328 & $1.38(1.09-1.76)$ & 0.008 \\
\hline \multicolumn{4}{|l|}{ Age (years) } \\
\hline 1. $76+$ & & Reff & \\
\hline 2. $71-75$ & 0.357 & $1.42(1.00-2.02)$ & 0.044 \\
\hline 3. $66-70$ & 0.543 & $1.72(1.25-2.36)$ & 0.001 \\
\hline 4. $60-65$ & 1.052 & $2.86(2.13-3.83)$ & 0.000 \\
\hline \multicolumn{4}{|l|}{ Region } \\
\hline 1. Rural & & Reff & \\
\hline 2. Urban & 0.637 & $1.89(1.61-2.21)$ & 0.000 \\
\hline \multicolumn{4}{|l|}{ Education } \\
\hline 1. Low & & Reff & \\
\hline 2. High & 0.737 & $2.08(1.66-2.61)$ & 0.000 \\
\hline \multicolumn{4}{|l|}{ Smoking behavior } \\
\hline 1. Never & & Reff & \\
\hline 2. Ever & -0.009 & $0.99(0.73-1.33)$ & 0.952 \\
\hline 3. Sometimes & -0.054 & $0.94(0.64-1.39)$ & 0.781 \\
\hline 4. Every day & -0.581 & $0.55(0.42-0.74)$ & 0.000 \\
\hline LDL cholesterol & & Reff & \\
\hline 3. $\operatorname{Normal}(<160 \mathrm{mg} / \mathrm{dL})$ & & & \\
\hline 4. $\operatorname{High}(\geq 160 \mathrm{mg} / \mathrm{dL})$ & 0.371 & $1.44(1.21-1.72)$ & 0.000 \\
\hline
\end{tabular}




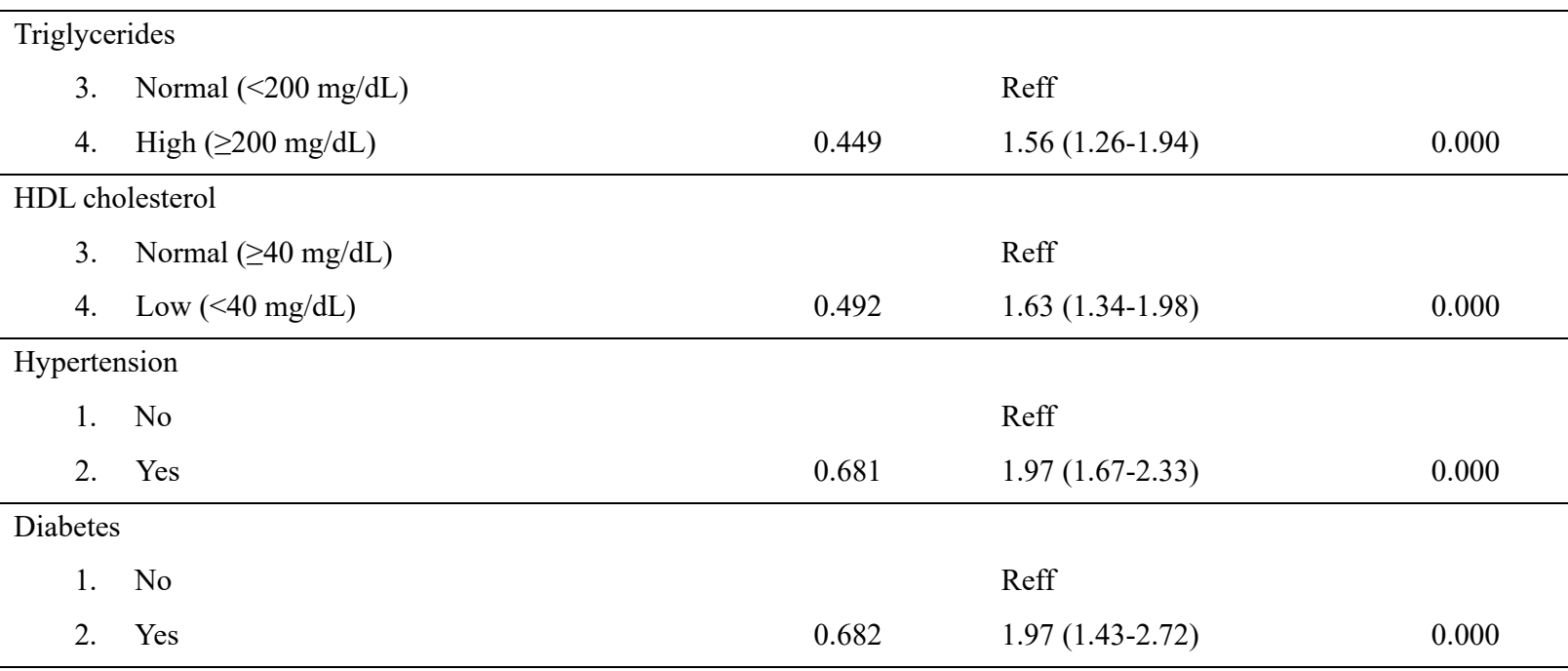

Smoking behavior has a significant inverse correlation with obesity in old age. Respondents who smoked every day had a protective risk of obesity of 0.55 times higher than that of those who had never smoked.

Based on the analysis of the metabolic syndrome variables, it appeared that the variables LDL, triglycerides, HDL, hypertension, and diabetes mellitus were associated with obesity status in older adults. Respondents with high LDL had a risk of obesity of 1.44 times higher than that of those with normal LDL. Respondents with high triglycerides had a risk of obesity of 1.56 times higher than that of those with normal triglycerides. Respondents with low HDL had a risk of obesity 1.63 times higher than that of those with normal HDL. Respondents who had hypertension had a risk of obesity 1.97 times than that of those without hypertension. Meanwhile, respondents with diabetes mellitus had a risk of obesity of 1.97 times higher than that of those without diabetes mellitus (Table 5).

\section{Discussion}

This study showed that the prevalence of obesity in older adults was found to be 17.6 percent, higher than the 2010 Riskesdas, although using a different cut-off (Ministry of Health Republic of Indonesia, 2010). The prevalence of obesity in the older adult population varied between countries: 0 percent in some Asian and African populations and more than 30 percent in some industrialized countries (Gutiérrez-Fisac et al., 2004; Ogden et al., 2006). The findings of this study were almost the same as in Malaysia, which found the prevalence of obesity in older adults of 17.7 percent (Lee, et al., 2019), which was higher than those of the study in Iran (Bakhshi et al., 2011) and lower than the findings of other studies (Raeisi et al., 2017).

The findings showed a relationship between gender and obesity in older adults: female respondents had a higher risk of becoming obese than male respondents. This was in line with other studies that found that obesity in women was higher than in men (Bakhshi et al., 2011; Raeisi et al., 2017). This was probably because women in old age rarely exercise measurably.

The risk of obesity was found to decrease with increasing age in old age. The relationship between age and obesity found in this study was basically in line with several studies (Gutiérrez-Fisac et al., 2004; Bakhshi et al., 2011; Kaplan et al., 2003; Chapman IM, 2008). In old age, changes in food intake, energy expenditure, appetite, and body composition occur, along with inevitable aging. With increasing age, there is a gradual loss of bone and muscle mass which affects body composition in older adults (Bakhshi et al., 2011). Over the age of 30, fat mass increases; while the free fat mass decreases. Free fat mass (especially skeletal muscle) decreases by up to 40 percent from that in the ages of 20 to 70 years. The maximum free fat mass is usually reached at the age of 20-30 years, and the maximum fat mass is usually reached at the age of 60-70 years. After that, both measures of fat decrease with increasing age (Villareal et al., 2005).

This study also showed that respondents in urban areas were at a greater risk of obesity compared to those who live in rural areas. This finding was in line with other studies (Bakhshi et al., 2011; Trinh et al., 2009; Gbary et al., 2014). Lifestyle changes in urban communities, such as consumption of fast food, which causes food imbalance, inadequate physical activity, which is caused by sedentary work and use of electronic equipment and motorized vehicles (Mokhtar et al., 2001). Besides, the lack of sports facilities and facilities in urban areas also makes urban people more comfortable living at home (Gbary et al., 2014). 
Respondents with higher education in this study had a higher risk of obesity than those with low education. This finding was in line with other studies (Bakhshi et al., 2011; Raeisi et al., 2017). Aitsi-Selmi et al., (2014) suggested that education modifies the relationship between wealth and obesity in middle-income countries. Highly educated women rarely do physical activity continuously because they are busy working at the desk.

Furthermore, this study also showed an association between smoking and obesity in older adults. Respondents who smoke every day were protective of becoming obese in old age. This finding was in line with that of research by Mackay et al. (2013) which stated that active smoking is associated with a reduced risk of being overweight in older adults (Mackay et al., 2013). Research findings in several cross-sectional studies showed that the average BMI of smokers tended to be lower than non-smokers (Huot et al., 2004; Clair et al., 2011; Varga et al., 2013; Liao et al., 2016). However, other studies reported that smokers were overweight and had a higher risk of obesity than non-smokers (Chiolero et al., 2008; Fasting et al., 2008). Research by Wang et al. (2016) found that there was no relationship between smoking and obesity, but found a relationship between ethnicity who smoked and obesity (Wang et al., 2016). Older adults who smoked for decades could suffer from lung disease, which tended to make them thinner (not obese) due to reduced oxygen intake due to the decreased/damaged lung function.

Smoking cessation is usually associated with increased body weight and changes in adipose cell metabolism resulting in increased activity of the enzyme lipoprotein lipase in adipose tissue. Increased activity of the lipoprotein lipase enzymes plays a role in weight gain associated with smoking cessation (Owen-Smith \& Hannaford, 1999; Ferrara et al., 2001). However, this does not mean that someone should keep smoking to avoid obesity in old age. Quitting smoking in old age, followed by regular physical activity, dietary food intake tends to reduce the risk of obesity.

Furthermore, this study showed an association between high LDL, high triglycerides, and low HDL and the incidence of obesity in older adults. A study by Zhang et al. (2019) showed that the LDL variable correlated with BMI in both men and women, while the HDL and triglyceride variables did not show a significant relationship (Zhang et al., 2019)

This study also showed an association between hypertension and diabetes and BMI. This was in line with the research in Shanghai, China (Zhang et al., 2019). Meanwhile, the research in Chinese elderly showed that the relationship between BMI and hypertension in older adults was different according to sex and age (Wang et al., 2018). Other epidemiological studies showed that central obesity indicators such as abdominal circumference and waist-to-hip ratio are more closely related to metabolic disease risk factors than BMI (Tran et al., 2018; Choi et al., 2018). This is likely because ectopic fat deposition triggers pathological metabolic reactions, which can increase the risk of metabolic disease (Piché et al., 2018)

The analysis of this study used secondary data from the 2013 Riskesdas, where the variables studied were limited to data availability. In this study, there were no recall data on food consumption, medication, and supplements which could be confounding variables related to obesity.

\section{Acknowledgments}

We would like to thank the Head of the Health Research and Development Agency who has facilitated the procurement of this research data and Dwi Hapsari Tjandrarini as a researcher supervisor for S, NS, and ON.

\section{Competing Interests Statement}

The authors declare that there are no competing or potential conflicts of interest.

\section{References}

Aitsi-Selmi, A., Bell, R., Shipley, M. J., \& Marmot, M. G. (2014). Education modifies the association of wealth with obesity in women in middle-income but not low-income countries: an interaction study using seven national datasets, 2005-2010. PloS one, 9(3), e90403. https://doi.org/10.1371/journal.pone.0090403

Bakhshi, E., Seifi, B., Biglarian, A., \& Mohammad, K. (2011). Factors associated with obesity in Iranian elderly people: Results from the national health survey. BMC Research Notes, 4, 2-7. https://doi.org/10.1186/1756-0500-4-538

Central Bureau of Statistics. (2015). Elderly population statistics 2014. Jakarta: Central Bureau of Statistics.

Chapman, I. M. (2008). Obesity in old age. Korbonits M (ed): Obesity and Metabolism. Front Horm Res. Basel, Karger, 36, 97-106. https://doi.org/10.1159/000115358

Chiolero, A., Faeh, D., Paccaud, F., \& Cornuz, J. (2008). Consequences of smoking for body weight, body fat distribution, and insulin resistance. American Journal of Clinical Nutrition, 87(4), 801-809. 
https://doi.org/10.1093/ajen/87.4.801

Choi, J. R., Koh, S. B., \& Choi, E. (2018). Waist-to-height ratio index for predicting incidences of hypertension: The ARIRANG study. BMC Public Health, 18(1), 4-9. https://doi.org/10.1186/s12889-018-5662-8

Clair, C., Chiolero, A., Faeh, D., Cornuz, J., Marques-Vidal, P., Paccaud, F., ... \& Vollenweider, P. (2011) 'Dose-dependent positive association between cigarette smoking, abdominal obesity and body fat: Cross-sectional data from a population-based survey. BMC Public Health, 11(1), p. 23. https://doi.org/10.1186/1471-2458-11-23

Mackay, D. F., Gray, L., \& Pell, J. P. (2013). Impact of smoking and smoking cessation on overweight and obesity: Scotland-wide, cross-sectional study on 40,036 participants. BMC public health, 13, 348. https://doi.org /10.1186/1471-2458-13-348

Ministry of Health Republic of Indonesia. (2010). Basic Health Research 2010. Jakarta: National Institute Health Research and Development.

Fasting, M. H., Nilsen, T. I., Holmen, T. L., \& Vik, T. (2008). Life style related to blood pressure and body weight in adolescence: Cross sectional data from the Young-HUNT study, Norway. BMC Public Health, 8, 1-10. https://doi.org/10.1186/1471-2458-8-111

Ferrara, C. M., Kumar, M., Nicklas, B., McCrone, S., \& Goldberg, A. P. (2001). Weight gain and adipose tissue metabolism after smoking cessation in women. Int $J$ Obes Relat Metab Disord, 25(9), 1322-1326. https://doi.org/10.1038/sj.ijo.0801716

Gbary, A. R., Kpozehouen, A., Houehanou, Y. C., Djrolo, F., Amoussou, M. P. G., Tchabi, Y., ... \& Houinato, D. S (2014). Prevalence and risk factors of overweight and obesity: findings from a cross-sectional community-based survey in Benin. Global Epidemic Obesity, 2(1), 3. https://doi.org/10.7243/2052-5966-2-3

Grundy, S. M., Becker, D., Clark, L. T., Cooper, R. S., Denke, M. A., Howard, W. J., et al. (2001) 'Executive Summary of the Third Report of the National Cholesterol Education Program (NCEP) Expert Panel on Detection, Evaluation, and Treatment of High Blood Cholesterol in Adults (Adult Treatment Panel III)', JAMA, 285(19), 2486-97. https://doi.org/10.1001/jama.285.19.2486

Guh, D. P., Zhang, W., Bansback, N., Amarsi, Z., Birmingham, C. L., \& Anis, A. H. (2009). The incidence of co-morbidities related to obesity and overweight: A systematic review and meta-analysis. BMC Public Health, 9, 1-20. https://doi.org/10.1186/1471-2458-9-88

Gutie'rrez-Fisac. J. L., Lo'pez, E., Banegas, J. R., Graciani, A., \& Rodr1'guez-Artalejo, F. (2004). Prevalence of overweight and obesity in elderly people in Spain. Obesity Research, 12(4), 710-715. https://doi.org/10.1038/oby.2004.83

Hitt, H.C., McMillen, R.C., Thornton-Neaves, T., Koch, K., \& Cosby, A.G. (2007). Comorbidity of obesity and pain in a general population: Results from the Southern Pain prevalence study. $J$ Pain, 8, 430-436. https://doi.org/10.1016/j.jpain.2006.12.003

Huot, I., Paradis, G., Ledoux, M., \& the Quebec Heart Health Demonstration Project research group. (2004). Factors associated with overweight and obesity in Quebec adults. Int J Obes Relat Metab Disord., 28(6), 766-774. https://doi.org/10.1038/sj.ijo.0802633

Jellinger, P. S., Handelsman, Y., Rosenblit, P. D., Bloomgarden, Z. T., Fonseca, V. A., Garber, A. J., ... \& Davidson, M. (2017). American Association of Clinical Endocrinologists and American College of Endocrinology Guidelines for Management of Dyslipidemia and Prevention of Cardiovascular Disease. Endocrine practice: official journal of the American College of Endocrinology and the American Association of Clinical Endocrinologists, 23(April), 1-87. https://doi.org/10.4158/EP171764.APPGL

Kaplan, M. S., Huguet, N., Newsom, J. T., McFarland, B. H., \& Lindsay, J. (2003). Prevalence and Correlates of Overweight and Obesity among Older Adults: Findings from the Canadian National Population Health Survey. Journals of Gerontology - Series A Biological Sciences and Medical Sciences, 58(11), 1018-1030. https://doi.org/10.1093/gerona/58.11.m1018

Lee, Y. Y., Kamarudin, K. S., \& Wan Muda, W. A. M. (2019). Associations between self-reported and objectively measured physical activity and overweight/obesity among adults in Kota Bharu and Penang, Malaysia. BMC Public Health, 19(1), 1-12. https://doi.org/10.1186/s12889-019-6971-2

Liao, C., Gao, W., Cao, W., Lv, J., Yu, C., Wang, S., ... \& Li, L. (2016). The association of cigarette smoking and alcohol drinking with body mass index: A cross-sectional, population-based study among Chinese adult male 
twins. BMC Public Health, 16(1), 1-9. https://doi.org/10.1186/s12889-016-2967-3

Lovejoy, J. C., Champagne, C. M., de Jonge, L., Xie, H., \& Smith, S. R. (2008). Increased visceral fat and decreased energy expenditure during the menopausal transition. Int $J$ Obes (Lond), 32(6), 949-958. https://doi.org/10.1038/ijo.2008.25

Mokhtar, N., Elati, J., Chabir, R., Bour, A., Elkari, K., Schlossman, N. P., ... \& Aguenaou, H. (2001). Diet culture and obesity in northern Africa. J Nutr, 131, 887S-892S. https://doi.org/10.1093/jn/131.3.887s

Ogden, C. L., Carroll, M. D., Curtin, L. R., McDowell, M. A., Tabak, C. J., \& Flegal, K. M. (2006). Prevalence of overweight and obesity in the United States, 1999-2004. JAMA, 295(13), 1549-1555. https://doi.org/10.1001/jama.295.13.1549

Ogston, S. A. (1991). Adequacy of Sample Size in Health Studies. Biometrics, 47(1), p. 347. https://doi.org/10.2307/2532527

Owen-Smith, V., \& Hannaford, P. C. (1999). Stopping smoking and body weight in women living in the United Kingdom. British Journal of General Practice, 49(449), 989-990

Piché, M. E., Poirier, P., Lemieux, I., \& Després, J. P. (2018). Overview of Epidemiology and Contribution of Obesity and Body Fat Distribution to Cardiovascular Disease: An Update, Prog Cardiovasc Dis, 61(2), 103-113. https://doi.org/10.1016/j.pcad.2018.06.004

Ponti, F., Santoro, A., Mercatelli, D., Gasperini, C., Conte, M., Martucci, M., Sangiorgi, L., Franceschi, C., \& Bazzocchi, A. (2020). Aging and Imaging Assessment of Body Composition: From Fat to Facts. Frontiers in Endocrinology, 10(January). https://doi.org/10.3389/fendo.2019.00861

Prentice, A. M., \& Jebb, S. A. (2001). Beyond body mass index. Obes Rev, 2(3), 141-147. https://doi.org/10.1046/j.1467-789x.2001.00031.x

Raeisi, A., Mehboudi, M., Darabi, H., Nabipour, I., Larijani, B., Mehrdad, N., ... \& Ostovar, A. (2017). Socioeconomic inequality of overweight and obesity of the elderly in Iran: Bushehr Elderly Health (BEH) Program. BMC Public Health, 17(1), 1-7. https://doi.org/10.1186/s12889-016-3912-1

Resnick, H. E., Carter, E. A., Aloia, M., \& Phillips, B. (2006). Cross-sectional relationship of reported fatigue to obesity, diet, and physical activity: results from the third national health and nutrition examination survey. $J$ Clin Sleep Med., 2(2), 163-169.

Scott, K. M., Bruffaerts, R., Simon, G. E., Alonso, J., Angermeyer, M., de Girolamo, G., .. \& Korff, M. V. (2008). Obesity and mental disorders in the general population: results from the world mental health surveys. International Journal of Obesity, 32(1), 192-200. https://doi.org/10.1038/sj.ijo.0803701

Scully, T. (2012). Demography: to the limit. Nature, 492. https://doi.org/10.1038/492S2a

Sudikno, Syarief, H., Dwiriani, C. M., \& Riyadi, H. (2015). Risk Factors of Overweight and Obese in Indonesian Adults (Analysis Data of Basic Health Research 2013). Gizindo, 38(2), 91-104. https://doi.org/10.36457/gizindo.v38i2.183.

Sun, G. Z., Li, Z., Guo, L., Zhou, Y., Yang, H. M., \& Sun, Y. X. (2014). High prevalence of dyslipidemia and associated risk factors among rural Chinese adults. Lipids in Health and Disease, 13(1). https://doi.org/10.1186/1476-511X-13-189

Tran, N. T. T., Blizzard, C. L., Luong, K. N., Truong, N. L. V., Tran, B. Q., Otahal, P., .. \& Callisaya, M. (2018). The importance of waist circumference and body mass index in cross-sectional relationships with risk of cardiovascular disease in Vietnam. PLoS ONE, 13(5), 1-13. https://doi.org/10.1371/journal.pone.0198202

Trinh, O. T. H., Nguyen, N. D., Phongsavan, P., Dibley, M. J., \& Bauman, A. E. (2009). Prevalence and risk factors with overweight and obesity among Vietnamese adults: Caucasian and Asian cut-offs. Asia Pacific Journal of Clinical Nutrition, 18(2), 226-233. https://doi.org/10.6133/apjen.2009.18.2.11

United Nations. (2019). World Population Prospects 2019. Retrieved from https://population.un.org/wpp/

Varga, T. V., Hallmans, G., Hu, F. B., Renström, F., \& Franks, P. W. (2013). Smoking status, snus use, and variation at the CHRNA5-CHRNA3-CHRNB4 locus in relation to obesity: The GLACIER study. American Journal of Epidemiology, 178(1), 31-37. https://doi.org/10.1093/aje/kws413

Villareal, D. T., Apovian, C. M., Kushner, R. F., \& Klein, S. (2005). Obesity in older adults: Technical review and position statement of the American Society for Nutrition and NAASO, the Obesity Society. Obesity Research, 13(11), 1849-1863. https://doi.org/10.1038/oby.2005.228 
Wang, P., Abdin, E., Sambasivam, R., Chong, S. A., Vaingankar, J. A., \& Subramaniam, M. (2016). Smoking and Socio-demographic correlates of BMI. BMC Public Health, 16(500), 1-7. https://doi.org/10.1186/s12889-016-3182-y

Wang, Q., Xu, L., Li, J., Sun, L., Qin, W., Ding, G., ... \& Xie, S. (2018). Association of anthropometric indices of obesity with hypertension in Chinese elderly: An analysis of age and gender differences. International Journal of Environmental Research and Public Health, 15(801), 1-14. https://doi.org/10.3390/ijerph15040801

WHO. (2012). Global Physical Activity Questionnaire (GPAQ) Analysis Guide (pp. 1-22). Geneva: World Health Organization.

WHO. (2000). Obesity: Preventing and managing the global epidemic. Geneva: World Health Organization.

WHO. (2007). Global Age-friendly Cities: A Guide. Community Health (p. 82). Geneva: WHO Press

Wolin, K. Y., Carson, K., \& Colditz, G. A. (2010). Obesity and Cancer. The Oncologist, 15, 556-565. https://doi.org/10.1634/theoncologist.2009-0285

Zhang, Y., Gu, Y., Wang, N., Zhao, Q., Ng, N., Wang, R., ... \& Zhao, G. (2019). Association between anthropometric indicators of obesity and cardiovascular risk factors among adults in Shanghai, China. BMC Public Health, 19(1035), 1-9. https://doi.org/10.1186/s12889-019-7366-0

Zhao, Q., Ma, X., Ge, X., Liu, F., Yan, W., Wu, L., ... \& the Neonatal Congenital Heart Disease screening group. (2014). Pulse oximetry with clinical assessment to screen for congenital heart disease in neonates in China: A prospective study. The Lancet, 384(9945), 746. https://doi.org/ 10.1016/S0140-6736(14)61316-7

\section{Copyrights}

Copyright for this article is retained by the author(s), with first publication rights granted to the journal.

This is an open-access article distributed under the terms and conditions of the Creative Commons Attribution license (http://creativecommons.org/licenses/by/4.0/). 